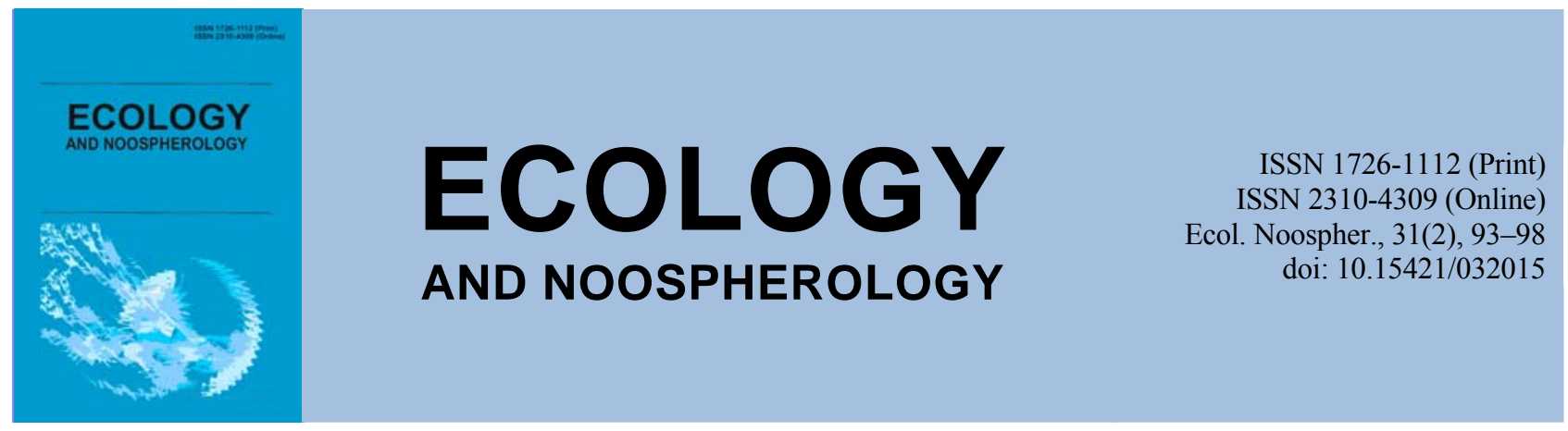

\title{
Influence of irrigated mineralized waters on properties of ordinary chernozem in the conditions of Prysamaria Dniprovske
}

\author{
E. P. Pochernyaeva, V. O. Okata, O. V. Kotovych, V. M. Yakovenko
}

Oles Honchar Dnipro National University, Dnipro, Ukraine

Article info

Received 08.10.2020

Received in revised form

17.10.2020

Accepted 25.10.2020

Oles Honchar Dnipro

National University,

Gagarin Ave., 72, Dnipro,

49010, Ukraine.

Tel.: +38-067-800-70-25

E-mail:bgz@ua.fm
Pochernyaeva, E. P., Okata, V. O., Kotovych, O. V., Yakovenko, V. M. (2020). Influence of irrigated mineralized waters on properties of ordinary chernozem in the conditions of Prysamaria Dniprovske. Ecology and Noospherology, 31(2), 93-98. doi:10.15421/032015

Irrigation of lands in arid climates helps to solve the problem of water deficit of soils in order to increase their fertility. However, under the influence of mineralized waters used for irrigation, there is a degradation of chemical, physico-chemical, water-physical and physical properties of soils. Soil monitoring is one of the effective mechanisms that allowsassessing the current state of soils and predicting the negative consequences of economic activity in the future. The area where the research was conducted is in the zone of insufficient moisture where there is an annual deficit of water balance of soils. Irrigation in the studied areas began in the mid-70s of the last century and lasted until 1992. The waters of the Samara River were used for this purpose. The total mineralization of water during the growing season reaches $3515 \mathrm{mg} / \mathrm{dm}^{3}$. It is possible to estimate the degree of transformation of soils that have been under the influence of irrigation waters for a long time in relation to the indicators of virgin soils. The zonal soils of the research area are CalcicChernozems. The analysis of macromorphological indicators showed that irrigation soils differ from the reference ones by the thickness of the organogenic horizon, density and structure. The results of the analysis of the aqueous extract of the reference soils show the absence of salinization with water-soluble salts. Their content varies in the range from 0.051 to $0.078 \%$. A maximum of one salt is observed in the soil profile, namely in the transitional horizon at a depth of 45-63 $\mathrm{cm}$. Below this depth, the content of water-soluble salts progressively decreases. The total content and distribution of water-soluble salts in the soil profile of irrigated soils has some differences from the reference soils. In the upper part of the humus horizon, the total amount of water-soluble salts is smaller, which can be attributed to the effects of machining and better aeration, as well as the intensive removal of their vegetation. Below these horizons, the amount of water-soluble salts progressively increases and reaches a maximum in the soil-forming rock. The nature of the distribution in the soil profile and the total amount of salts isnot typical for Calcic Chernozems and ismore similar to those of Gleyic Calcic Chernozems. The maximum amount of water-soluble salts is concentrated in the parent rock. Their percentage indicates the absence of salinity in both studied soils. But guided by the method of calculating the content of toxic water-soluble salts in the soil, in the reference soils, this figure reaches $0.21 \mathrm{t} / \mathrm{ha}$ in a meter layer of soil, and in irrigation $0.42 \mathrm{t} / \mathrm{ha}$. The results of studies of physicochemical parameters show that a higher content of metabolic calcium is characteristic of the reference soils, and its distribution in the soils along the profile of both options is relatively similar. In contrast, the distribution of exchangeable magnesium in the soil profile varies greatly, especially in the reference soils. In irrigated soils, the ratio of exchangeable calcium to magnesium is more stable and varies in the range from 4.2 to 7.9 , which may be the result of prolonged irrigation. According to the obtained physicochemical parameters, irrigation soils have weak salinity in the lower part of the transition horizon. This indicator, together with the ratio of exchangeable calcium to magnesium, indicates eluvial-illuvial processes that for some time contributed to the redistribution in the soil profile of both water-soluble salts and exchangeable cations. Evaluation of the degree of salinity of soils showed the absence of salinization in the reference soils, as well as in the upper part of the humus horizons of irrigated soils. Given the buffering of irrigated soils, weak salinity is present only in the upper part of the transition horizon.

Keywords: morphological parameters of soils; irrigation; salinity; toxic ions; physicochemical properties 


\title{
Вплив зрошувальних мінералізованих вод на властивості чорноземів звичайних в умовах Присамар'я Дніпровського
}

\author{
Є. П. Почерняєва, В. О. Оката, О. В. Котович, В. М. Яковенко \\ Дніпровський національний університет імені Олеся Гончара, Дніпро, Україна
}

\begin{abstract}
Деградація грунтів під впливом зрошення є одним з факторів погіршення їхнього стану. Для оцінки негативних змін, які виникають внаслідок зрошення грунтів мінералізованими водами, використовують інтегральну оцінку ступеня іригаційної деградації. Відповідно до оцінки проведено порівняльний аналіз змін щодо вмісту і розподілу водорозчинних сполук і фізико-хімічних показників чорноземних грунтів, які майже 30 років зрошувались водами р. Самари. Проведені дослідження показали відмінності зрошувальних і еталонних грунтів відповідно до обраних показників. Так, відмічаються певні відмінності у структурі грунтових агрегатів у нижній частини гумусових і перехідних горизонтів. Зокрема, призматично-грудкувато-брилиста структура нижньої частини перехідного горизонту зрошувальних грунтів може свідчити про наявність ілювіальних процесів у минулому. Результати аналізу водної витяжки показали відсутність засолення водорозчинними солями як в еталонних грунтах, так і в зрошувальних. При цьому загальна кількість токсичних водорозчинних солей у зрошувальних грунтах у два рази більша, ніж відповідний показник еталонних грунтів. Аналіз фізико-хімічних показників показав, що зрошувальні грунти мають слабку солонцюватість у нижній частині перехідного горизонту. Цей показник разом з відношенням обмінних кальцію та магнію свідчить про елювіально-ілювіальні процеси, які протягом певного часу сприяли перерозподілу в грунтовому профілі як водорозчинних солей, так і обмінних катіонів.
\end{abstract}

Ключові слова: морфологічні показники; зрошення; засолення; токсичні йони; фізико-хімічні властивості

\section{Ветуп}

Зрошення земель в умовах посушливого клімату допомагає вирішити проблему дефіциту водного балансу грунтів 3 метою підвищення їх родючості. Разом з тим під впливом мінералізованих вод, які використовуються для іригації, відбувається деградація хімічних, фізико-хімічних, водно-фізичних і фізичних властивостей грунтів. Ступінь іригаційної деградації визначається рівнем відхилення від оптимуму основних параметрів грунту, які є визначальними для формування їх родючості (Baliuk, 2015).

Моніторинг грунтів $є$ одним 3 дієвих механізмів, що дозволяє оцінювати сучасний стан грунтів і прогнозувати негативні наслідки від господарської діяльності в майбутньому. Одним із засобів оцінки негативних змін властивостей зрошувальних грунтів $\epsilon$ інтегральна оцінка ступеня іригаційної деградації (Baliuk, 2006, 2009; Romashhenko, 2000).

\section{Матеріали та методи досліджень}

В основу грунтових досліджень нами було покладено грунтово-геохімічний методологічний підхід, 3 використанням методу грунтово-режимних спостережень та методів, які використовуються при комплексному еколого-агромеліоративному обстеженні земель (Instructions, 2002; Medvedev, 2012). Лабораторні дослідження фізичних, фізико-хімічних та хімічних властивостей грунтів проводили відповідно до діючих державних стандартів України.

Територія, де проводились дослідження, знаходиться у зоні недостатнього зволоження, де щорічно спостерігається дефіцит водного балансу грунтів (Kotovych et al., 2019). За фізико-географічним поділом відноситься до Північностепової зони. В адміністративному плані розташована в Дніпропетровській області, Новомосковському районі, поблизу с. Андріївки ( $\left.48^{\circ} 45^{\prime} 36.9^{\prime \prime} \mathrm{N}, 35^{\circ} 27^{\prime} 40.5^{\prime \prime} \mathrm{E}\right)$.

Зрошення на досліджуваних ділянках почалось із середини 70-х років минулого сторіччя і тривало до 1992 року. Для цього використовували води річки Самари. Загальна мінералізація води річки Самари не є сталим показником і змінюється протягом року в інтервалі від 1936 до 3515 мг/дм³ (Varenko et al., 1992; Kotovych, 2015). Іонний склад річкової води за співвідношенням іонів відноситься до сульфатного класу, натрієвої групи третього типу. Реакція $\mathrm{pH}$ - слабколужна. За ступенем жорсткості - дуже жорстка.
Оцінка якості води відповідно до агрономічних критеріїв показала, що вода за небезпекою вторинного засолення грунтів на основі показника концентрації токсичних іонів в еквівалентах хлору відноситься до першого класу якості, але за кількістю токсичних іонів в 9,6 мекв/дм³ цей показник знаходиться на межі, відповідно до якої здійснюють поділ на перший і другий клас якості. За небезпекою підлуження грунту - до другого класу якості, токсична лужність - 4,05 мекв/дм ${ }^{3}$. За небезпекою осолонцювання грунтів - до першого класу якості. При цьому, як і у випадку з оцінкою води за небезпекою вторинного засолення грунтів, відсотковий сумарний уміст $\mathrm{Na}^{+}$та $\mathrm{K}^{+}$без урахування $\mathrm{Mg}^{2+}$ становить $43,5 \%$, що також знаходиться на межі, відповідно до якої здійснюють поділ на перший і другий клас якості.

\section{Результати та їх обговорення}

Оцінити ступінь трансформації грунтів, які знаходились протягом тривалого часу під дією впливу іригаційних вод, можна відносно показників, що мають цілинні грунти. Зональні грунти району досліджень чорноземи звичайні карбонатні малогумусові важкосуглинкові пилувато-мулуваті на лесах (Bilova et al., 1999), класифікація грунтів за IUSS Working Group WRB (2015) - Calcic Chernozems (Yakovenko et al., 2018). У будові грунтового профілю виділяють два гумусових горизонти, два перехідних та материнську породу:

$\mathbf{H}_{\mathbf{d}}(0-7 \mathrm{~cm})$ : дерновий горизонт із залишками степової рослинності.

$\mathbf{H}_{1}$ (7-26 см): суглинковий гумусово-акумулятивний горизонт, темно-сірого кольору, пилувато-дрібнозернистої структури, пухкий. Корені трав'яних рослин утворюють суцільний дерновий покрив. Перехід до наступного горизонту чіткий за структурою, зростанням щільності та зменшенням умісту кореневих систем.

$\mathbf{H}_{2} \quad(26-42$ см): другий гумусово-акумулятивний горизонт, темно-сірого кольору, свіжий, дрібнозернистий, менш корененасичений, середньосуглинковий. На структурних окремостях помітний наліт присипки $\mathrm{SiO}_{2}$. Перехід до наступного горизонту поступовий за забарвленням і структурою.

Нр (42-57 см): перший перехідний горизонт, темносірого з бурим кольору, свіжий, ущільнений. Коренева насиченість слабка. Структура дрібнозерниста грудкуватобрилиста. Перехід до наступного горизонту поступовий за кольором та наявністю новоутворень. 
Phk (57-96 см): другий перехідний горизонт, палевобурого кольору, свіжий, ущільнений. Новоутворення із карбонатів кальцію у вигляді білозірки. Структура грудкувато-брилиста. Закипає від 10\%-ного $\mathrm{HCl} з$ глибини 65 см. Перехід до наступного горизонту поступовий за забарвленням та структурою.

Pk (96-130 см): лесова материнська порода, темнобуро-жовтого кольору, важкосуглинкова, структура призматична, брилиста, щільна, зустрічаються скупчення карбонатів у вигляді білозірки.

Аналіз макроморфологічних показників показав, що зміни властивостей профілю грунту, а саме кольору, щільності, структури, відбуваються поступово без різких змін. Виняток складає перехід між окремими горизонтами у верхній частині грунтового профілю, де спостерігається різка зміна щільності і структури грунту, що насамперед пов'язано 3 діяльністю рослин, а саме зі ступенем корененасиченості.

Грунтовий профіль орних, зрошувальних грунтів має таку будову:

Н $_{\text {1орн. }} \quad(0-8$ см$):$ орний гумусово-акумулятивний горизонт, світло-сірого кольору, сухий, структура брилисто-порохувата, складення щільне, тріщинуватий, перехід до наступного горизонту поступовий за забарвленням, зволоженням, структурою i щільністю складення.

$\mathbf{H}_{2} \quad(8-22$ см): гумусово-акумулятивний підорний горизонт, темно-сірого кольору, свіжий, структура брилисто-грудкувата, брилисті окремості різного розміру, щільного складення, порівняно 3 попереднім горизонтом не тріщинуватий, перехід до наступного горизонту за структурою і щільністю ясний.

$\mathbf{H}_{3}$ (22-56 см): гумусово-акумулятивний горизонт, темно-сірого кольору, грудкувато-брилистої структури, меншої щільності за попередній горизонт, містить кореневі системи рослин, свіжий, перехід до наступного горизонту за структурою і кольором поступовий.

Нр (56-65 см): перший перехідний горизонт, темносірого 3 палевим відтінком кольору, свіжий, структура призматично-грудкувато-брилиста, менш щільний від попереднього горизонту, помітні скупчення карбонатів кальцію у вигляді конкрецій розміром 1-5 мм у діаметрі, перехід до наступного горизонту за кольором.

Phk (65-84 cм): другий перехідний горизонт, бруднопалевого кольору із сірими плямами і смугами, структура призматично-грудкувато-брилиста. За щільністю подібний до попереднього горизонту. Закипає від 10\%-ного $\mathrm{HCl} 3$ глибини 78 см. Свіжий, перехід до наступного горизонту за забарвленням.

Pk (84-125 см): материнська порода (лес) палевого кольору 3 білими вкрапленнями карбонатів у вигляді білозірки. Грудкувата структура, брилиста, призматична, свіжа, гранулометричний склад - суглинковий.

Назва грунту - чорнозем звичайний карбонатний малогумусовий слабозмитий середньосуглинковий на лесах.

Грунтовий профіль цих грунтів має схожу будову із зональними грунтами, описану вище, але при цьому, крім наявності орного горизонту, $\epsilon$ певні відмінності у морфологічних властивостях i загальних рисах. Так, загальна потужність органогенного горизонту в еталонних грунтах більша на $10 \mathrm{~cm}$, ніж у зрошувальних грунтів. Певні відмінності спостерігаються у структурі нижньої частини гумусового горизонту. Для нижньої частині гумусового горизонту еталонних грунтів властива дрібнозерниста структура, у противагу цьому відповідна частина грунтового профілю зрошувальних грунтів має грудкувато-брилисту структуру. Крім того, у зрошувальних грунтах для нижньої частини перехідного горизонту властива призматично-грудкувато-брилиста структура, що може свідчити про наявність ілювіальних процесів у минулому. Для еталонних грунтів призматична структура властива лише для материнської породи.

Результати аналізу водної витяжки еталонних грунтів показують відсутність засолення водорозчинними солями (табл. 1). Їх уміст змінюється в інтервалі від 0,051 до 0,078 \%. У грунтовому профілі відмічається один сольовий максимум, а саме в перехідному горизонті на глибині $60 \mathrm{~cm}$. Цю відмітку можна умовно приймати за нижню межу елювіювання водорозчинних солей і глибину сезонного промочування грунту. Нижче вміст водорозчинних солей прогресивно зменшується.

Якісний склад іонів характеризується переважанням у складі аніонів бікарбонатів, кількість яких у перехідному горизонті також максимальна. За відсотковим умістом серед катіонів домінує кальцій, максимальний уміст якого є у материнської породі. Показовим $\epsilon$ підвищений уміст водорозчинних сполук калію у верхніх горизонтах, походження якого можна пов'язати зі степовою рослинністю.

Загальний уміст і розподіл водорозчинних солей у грунтовому профілі зрошувальних грунтів має певні відмінності від еталонних грунтів. У верхньої, орної і підорної частин профілю загальна кількість водорозчинних солей менша, що можна пов'язати з наслідками механічної обробки і кращою аерацією, а також інтенсивним виносом ix рослинністю. Нижче цих горизонтів кількість водорозчинних солей прогресивно збільшується і сягає максимуму у грунтотвірній породі. Характер розподілу у грунтовому профілі та загальна кількість солей не властиві для чорноземів звичайних і більше схожі на показники, які мають лучно-чорноземні грунти.

Більш високий уміст водорозчинних сульфатів i хлоридів у порівнянні 3 еталонними грунтами може бути наслідком впливу мінералізованих вод. Максимальна кількість водорозчинних катіонів сконцентрована в материнській породі. Підвищений уміст водорозчинних солей у грунтовому профілі зрошувальних грунтів свідчить про наявність процесів засолення та існування умов для їх осолонцювання в минулому.

Відсотковий уміст загальної суми водорозчинних солей свідчить про відсутність засолення в обох досліджуваних грунтах. Але, керуючись методикою розрахунку вмісту токсичних водорозчинних солей у грунті (Instructions, 2002), відповідно до якої враховують як токсичні солі всі іони хлору, бікарбонат- та сульфат-іони не зв'язані із кальцієм, а також іони магнію, натрію та калію, можна відзначити наявність токсичних іонів як у грунтах еталонних ділянок, так і в зрошувальних грунтах. Так, в еталонних грунтах цей показник сягає 0,21 т/га у метровому шарі грунту, а у зрошувальних 0,42 т/га.

Результати досліджень фізико-хімічних показників показують, що більш високий уміст обмінного кальцію властивий для еталонних грунтів, причому його розподіл у грунтах вздовж профілю обох випадках відносно однаковий (табл. 2). У противагу цьому розподіл обмінного магнію в грунтовому профілі сильно варіює перш за все в еталонних грунтах. У зрошувальних грунтах відношення обмінного кальцію до магнію більш стале і змінюється в інтервалі від 4,2 до 7,9, що може бути наслідком тривалого зрошення.

Оцінка ступеня солонцюватості грунтів показала відсутність осолонцювання в еталонних грунтах, що підтверджує раніше проведені дослідження (Gorban et al., 2020), а також у верхній частині гумусових горизонтів зрошувальних грунтів. 3 урахуванням буферності зрошувальних грунтів слабка солонцюватість присутня лише у верхній частині перехідного горизонту.

Таким чином, можна відзначити, що майже через 30 років чорноземні грунти під впливом іригаційних вод мають негативні наслідки за вмістом токсичних йонів $\mathrm{i}$ вмістом обмінного натрію. 
Таблиця 2

Фізико-хімічні показники досліджуваних грунтів

\begin{tabular}{|c|c|c|c|c|c|c|c|c|c|}
\hline \multirow{2}{*}{$\begin{array}{c}\text { Глибина } \\
\text { відбору } \\
\text { зразків, см }\end{array}$} & \multicolumn{4}{|c|}{ Поглинуті катіони, мг-екв/100 г /100г } & \multirow{2}{*}{$\begin{array}{c}\mathrm{H}^{+} \\
\text {мГ-екв/100 г }\end{array}$} & \multirow{2}{*}{$\begin{array}{c}\text { Відношення } \\
\text { обм. } \mathrm{Ca}^{2+} \\
\text { до } \mathrm{Mg}^{2+}\end{array}$} & \multirow{2}{*}{$\begin{array}{c}\text { Смність } \\
\text { ГПК грунту, } \\
\text { мГ-екв/100 г }\end{array}$} & \multirow{2}{*}{$\begin{array}{c}\mathrm{CaCO}_{3}, \\
\%\end{array}$} & \multirow{2}{*}{$\begin{array}{c}\text { Відношення } \\
\text { обм. } \mathrm{K}^{+}+ \\
\mathrm{Na}^{+} \text {до } \\
\text { ємності } \\
\text { ГПК, \% }\end{array}$} \\
\hline & $\mathrm{Ca}^{2+}$ & $\mathrm{Mg}^{2+}$ & $\mathrm{Na}^{+}$ & $\mathrm{K}^{+}$ & & & & & \\
\hline \multicolumn{10}{|c|}{ Чорнозем звичайний, степова цілина } \\
\hline $0-7$ & 30,4 & 7,2 & - & 0,01 & 0,22 & 4,2 & 37,83 & - & 0,03 \\
\hline $7-26$ & 31,5 & 5,8 & - & 0,02 & 0,16 & 5,4 & 37,48 & - & 0,05 \\
\hline $26-42$ & 30,5 & 2,3 & - & 0,06 & 0,11 & 13,3 & 32,97 & - & 0,18 \\
\hline $42-57$ & 31,4 & 1,5 & - & 0,04 & - & 20,9 & 32,94 & 2,1 & 0,12 \\
\hline $57-96$ & 29,8 & 1,5 & 0,04 & 0,12 & - & 19,9 & 31,46 & 8,7 & 0,51 \\
\hline $96-130$ & 30,1 & 1,3 & - & 0,04 & - & 23,2 & 31,44 & 9,2 & 0,13 \\
\hline \multicolumn{10}{|c|}{ Чорнозем звичайний, зрошувальні ділянки } \\
\hline $0-8$ & 29,1 & 7,0 & - & 0,09 & 0,98 & 4,2 & 37,17 & - & 0,24 \\
\hline $8-22$ & 28,7 & 6,5 & - & 0,11 & 0,81 & 4,4 & 36,12 & - & 0,30 \\
\hline $22-56$ & 28,3 & 4,2 & - & 0,37 & 0,50 & 6,7 & 33,37 & - & 1,11 \\
\hline $56-65$ & 28,7 & 4,2 & 0,12 & 0,24 & - & 6,8 & 33,26 & 1,9 & 1,08 \\
\hline $65-83$ & 29,1 & 3,7 & 0,24 & 0,19 & - & 7,9 & 33,23 & 7,1 & 1,29 \\
\hline $83-125$ & 29,0 & 3,9 & 0,35 & 0,21 & - & 7,4 & 33,46 & 8,8 & 1,67 \\
\hline
\end{tabular}

\section{Висновки}

Оцінка якості зрошувальних вод показала, що вода за небезпекою вторинного засолення грунтів відноситься до першого класу якості, кількість токсичних іонів відповідає межі, відповідно до якої здійснюють поділ на перший i другий класи якості. За небезпекою підлуження грунту до другого класу якості - присутня токсична лужність. За небезпекою осолонцювання грунтів - до першого класу якості з тенденцією переходу до другого класу якості.

Морфологічні показники досліджених грунтів мають певні відмінності у структурі грунтових агрегатів - для нижньої частини гумусового горизонту еталонних грунтів властива дрібнозерниста структура, відповідна частина грунтового профілю зрошувальних грунтів має грудкуватобрилисту структуру. Нижня частина перехідного горизонту зрошувальних грунтів має призматичногрудкувато-брилисту структуру, що свідчить про наявність ілювіальних процесів у минулому.

Результати аналізу водної витяжки показують відсутність засолення водорозчинними солями як в еталонних грунтах, так i в зрошувальних. Загальна кількість токсичних водорозчинних солей у зрошувальних грунтах у два рази більша, ніж відповідний показник еталонних грунтів.

Щодо отриманих фізико-хімічних показників зрошувальні грунти мають слабку солонцюватість у нижній частині перехідного горизонту. Цей показник разом $з$ відношенням обмінних кальцію до магнію свідчить про елювіально-ілювіальні процеси, які протягом певного часу сприяли перерозподілу в грунтовому профілі як водорозчинних солей, так і обмінних катіонів.

\section{References}

Baliuk, S., Zakharova, M., Drozd, E., Nosonenko, A., Vorotyntseva, L., Afanasyev, Yu. Scientific approaches to the irrigational soil degradation assessment and ways to prevent or overcome it for securing the sustainable development of agriculture in

Ukraine https://www.sworld.com.ua/konfer39/36.pdf

Baliuk, S., Romashhenko, M. (2006). Naukovi aspekty stalogo rozvitku zroshenya zemel $\mathrm{v}$ Ukrayini [Scientific aspects of sustainable development of land irrigation in Ukraine]. Kyiv (in Ukrainian).
Baliuk, S., Romashhenko, M., Stashuk, A. (2009). Naukovi osnovy ohorony ta racionalnogo vykorystanya zroshuvalnyh zemel Ukrayiny [Scientific bases of protection and rational use of irrigated lands of Ukraine]. Kyiv (in Ukrainian).

Bilova, N. A., Travleyev, A. P. (1999). Estestvenye lesa i stepnye pochvy [Natural forests and steppe soils]. DNU, Dnipro (in Russian).

Budanov, M. F. (1970). Sistema i sostav kontrolya za kachestvom prirodnyh i stochnyh vod pri ispolzovanii ih dlya orosheniya [System and composition of control over the quality of natural and waste waters when using them for irrigation]. Urozhay, Kyiv (in Russian).

Gorban, V., Huslystyi, A., Kotovych, O., Yakovenko, V. (2020) Changes in physical and chemical properties of Calcic chernozem affected by Robinia pseudoacaciaand Quercus robur plantings. Ekológia (Bratislava), 39, 1, 27-44.

Instrukciya $\mathrm{Z}$ provedenya gruntovo-solovoj zyomku na zroshuvalnyh zemlyah Ukrayiny: VND 33-5.5-11-02., (2002). [Instructions for soil and salt survey on irrigated lands of Ukraine: VND 33-5.5-11-02.]. Derjvodgosp Ukrayiny, Kyiv (in Ukrainian).

IUSS Working Group WRB. 2015. World Reference Base for Soil Resources 2014, update 2015 International soil classification system for naming soils and creating legends for soil maps. World Soil Resources Reports No. 106. FAO, Rome.

Kotovych, O. V., Recio Espejo, J. M., Yakovenko, V. M., Dubina, A. O., Karas, O. G., Travleyev, L. P.. (2019) Hydrological constants and water regime of a Calcic Chernozems in the zone of true steppe of Ukraine. Fundamental and Applied Soil Science, 19(2), 51-54.

Kotovych, O. V. (2015). Ekologo-gidrochimichna harakteristika gruntovyh vod Prisamarya Dniprovskogo yak indikator stanu etalonyh ta destruktivnyh biogeocenoziv [Ecological and hydrochemical characteristics of groundwater of Prysamary Dnieper as an indicator of the state of reference and destructive biogeocenoses]. Gruntoznavstvo, 16 (1-2), 89-101 (in Ukrainian).

Medvedev, V. V. (2012). Monitoring poshv Ukrayiny. Koncepciya. Itogi. Zadashi [Monitoring of soils in Ukraine. Concept. Results. Tasks]. Gorodskaya tipografiya, Kharkov (in Russian).

Romashhenko, M., Baliuk, S. (2000). Zroshenya zemel v Ukrayine. Stan ta shlyahi polipshenya [Irrigation of lands in Ukraine. Condition and ways to improve]. Svit, Kyiv (in Ukrainian). 
Soils. Klasifikaciya gruntiv za stupenem vtorynoj soloncyvatosti (1999). [Classification of soils by the degree of secondary salinity]. Derjstandart, Kyiv (in Ukrainian).

Varenko, N., Kovtun, T., Murzina, T. (1992). Izmenenie himicheskogo sostava vody reki Samary (Dneprovskoj) pod vliyaniem hozyaystvenoj deyatelnosti [Changes in the chemical composition of the water of the Samara (Dnieper) river under the influence of economic activities]. Gidrobilogisheskiy jurnal, 28, (5), 93-98 (in Russian).

Yakovenko, V. M., Bilova, N. A. (2018). Biogene mikrostrukturoutvorenya lsovyh gruntiv stepovoy zony Ukrayiny [Biogenic microstructure formation of forest soils of the steppe zone of Ukraine]. Serednyak, Dnipro (in Ukrainian). 